\title{
Feeding Value of Rice Whole Crop Silage as Compared to Those of Various Summer Forage Crop Silages
}

\author{
Masakazu Goto, Osamu Morita, Kenji Nishiwaki \\ and Atsushi Nakashima \\ Faculty of Bioresources, Mie University, Tsu-shi 514
}

(Received February 28, 1990)

Key words : Feeding value, Rice plant, Whole crop silage

Much recent work on ruminant feeds has concentrated on cereal straw and its upgrading with chemical and physical treatments, due mainly to large supply of rice straw in the most of area in Japan. In addition to rice and wheat straws, whole crop silage of rice plant are receiving attention as an advantageous feed production system in paddy field ${ }^{4)}$. The objective of this study was to determine the feeding value of whole crop silage of rice plant as compared to those of various summer forage crop silages.

\section{Materials and Methods}

Rice crop (Oryza sativa L. cv., Yamahikari), Italian ryegrass (Lolium multiflorum Lam. cv., Common), Japanese millet (Echinochloa frumentacea Link. cv., Green) and sorghum (Sorghum bicolor Moench. cv., FS $401 \mathrm{R}$ ) were grown in the Mie Animal Husbandary Experimental Station. The forage crops were harvested at various growth stages and ensiled during different periods ; rice crop (yellow ripe stage, 60 days), Italian ryegrass (flowering stage, 150 days), Japanese millet (flowering stage, 90 days) and sorghum (heading stage, 60 days). Dry matter concentration of each silage was determined by the toluene distillation method, and the organic acids was by FLIEG's method ${ }^{10}$.

Voluntary intake and apparent digestibilities of dietary components were measured with four individually-penned Holstein heifers (average weight: $325 \mathrm{~kg}$ ) in a 4-treatment changeover design. Each trial consisted of a 6-day preliminary period followed by a 4-day measurement period. Each silage was offered ad libitum to the cattle twice a day as the sole feed. Apparent digestibilities of DM, crude protein, crude fiber, NFE, and crude fat were determined from the analysis of feedstuffs and feces collected daily during the measurement period $^{6)}$. Eating and ruminating behavior of two settled heifers was also observed by two observers allotted for each cattle during last 2-day measurement period, using a stopwatch and counter ${ }^{3)}$.

\section{Results and Discussion}

The rice crop silage was much poorer in fermentative quality due to high $\mathrm{pH}$ value

夏咱料作物サイレージとの比較からみた水稲ホールクロップサイレージの飼料価值：後藤正和・森田 脩・西脇謙 二・中島敨司（三重大学生物資源学部 津市 514 ) 
Feeding Value of Rice Whole Crop Silage as Compared to Summer forage crops

and high percentage of butyric acid to total organic acids produced, while those of sorghum, Italian ryegrass and Japanese millet were fermentated well; i.e., lactic and acetic acids were preferentially produced (Table 1). Rice crop silage had much higher NFE and corresponding lower crude fiber contents than the other forage crops, but lower digestibility of crude fiber. The rice crop silage had $496 \mathrm{~g}$ $\mathrm{kg}^{-1}$ of TDN content with less $120 \mathrm{~g} \mathrm{~kg}^{-1}$ and $100 \mathrm{~g} \mathrm{~kg}^{-1}$ of that value than Italian ryegrass and sorghum silages, respectively. Dry matter intake of dairy cattle fed on ad libitum was considerably higher for rice crop silage $(83.6$

Table 1. Fermentative quality and feeding values of forage crop silages

\begin{tabular}{|c|c|c|c|c|}
\hline & $\begin{array}{l}\text { Rice } \\
\text { crop }\end{array}$ & $\begin{array}{l}\text { Italian } \\
\text { ryegrass }\end{array}$ & $\begin{array}{l}\text { Japanese } \\
\text { millet }\end{array}$ & Sorghum \\
\hline \multicolumn{5}{|l|}{ Fermentative quality } \\
\hline Moisture (g kg-1) & 650 & 795 & 743 & 815 \\
\hline $\mathrm{pH}$ & 4.6 & 4.0 & 4.2 & 3.7 \\
\hline \multicolumn{5}{|c|}{ Organic acid $(\%$ of $\mathrm{FW})$} \\
\hline Lactic acid & 0.41 & 1.49 & 0.89 & 1.54 \\
\hline Acetic acid & 0.73 & 0.70 & 0.14 & 0.42 \\
\hline Butyric acid & 0.69 & 0.22 & 0.04 & 0.00 \\
\hline Total & 1.83 & 2.41 & 1.07 & 1.96 \\
\hline \multicolumn{5}{|c|}{ Composition of DM ( $\left(\mathrm{g} \mathrm{kg}^{-1}\right)$} \\
\hline Crude protein & 67 & 81 & 66 & 88 \\
\hline Crude fiber & 242 & 375 & 357 & 338 \\
\hline $\mathrm{NFE}$ & 545 & 398 & 458 & 439 \\
\hline Crude fat & 29 & 56 & 29 & 60 \\
\hline Crude ash & 117 & 90 & 90 & 75 \\
\hline \multicolumn{5}{|c|}{ Nutrient composition $(\mathrm{g} \mathrm{kg-1})$} \\
\hline DCP & 29 & 30 & 16 & 44 \\
\hline TDN & 496 & 616 & 486 & 596 \\
\hline \multicolumn{5}{|l|}{ Digestibility $(\mathrm{g} \mathrm{kg}-1)$} \\
\hline Dry matter & $482 \mathrm{c}$ & $595 a$ & $454 d$ & $543 b$ \\
\hline Crude protein & $425 b$ & $374 b$ & $242 \mathrm{c}$ & $505 \mathrm{a}$ \\
\hline Crude fiber & $412 \mathrm{c}$ & $710 a$ & $604 b$ & $611 b$ \\
\hline NFE & $510 \mathrm{a}$ & $554 b$ & $472 \mathrm{c}$ & $524 \mathrm{C}$ \\
\hline Crude fat & $542 c$ & $788 \mathrm{~b}$ & $588 \mathrm{c}$ & $853 a$ \\
\hline $\begin{array}{l}\text { Voluntary intake of } \\
\left(\mathrm{g} \mathrm{kg}^{-1} \mathrm{~W}^{0,75}\right)\end{array}$ & $83.6 a$ & $65.1 b$ & $67.3 b$ & $69.8 b$ \\
\hline \multicolumn{5}{|c|}{$\begin{array}{l}\text { Eating and ruminating behavior } \\
\text { Eating time (min. } \mathrm{kg}^{-1} \text { DM intake) }\end{array}$} \\
\hline Cattle A & 28.7 & 30.0 & 51.0 & 45.0 \\
\hline Cattle B & 44.6 & 62.3 & 73.0 & 52.5 \\
\hline \multicolumn{5}{|c|}{ Rumination time (min. $\mathrm{kg}^{-1} \mathrm{DM}$ intake) } \\
\hline Cattle A & 41.9 & 47.9 & 44.1 & 50.0 \\
\hline Cattle B & 50.0 & 66.7 & 51.1 & 60.8 \\
\hline \multicolumn{5}{|c|}{ Chewing number ( $100 \mathrm{sec}^{-1}$ bolus $\left.^{-1}\right)$} \\
\hline Cattle A & $110.9 \mathrm{c}$ & $121.8 \mathrm{a}$ & $117.6 \mathrm{~b}$ & $123.6 \mathrm{a}$ \\
\hline Cattle B & $115.6 \mathrm{c}$ & $134.1 \mathrm{a}$ & $113.6 \mathrm{c}$ & $126.3 \mathrm{~b}$ \\
\hline
\end{tabular}

1) Figures with different superscript letters are significantly different at the $5 \%$ level (Duncan's multiple range test). 
$\left.\mathrm{g} \mathrm{kg}^{-1} \mathrm{~W}^{0.75}\right)$ than for Italian ryegrass $(65.1 \mathrm{~g}$ $\left.\mathrm{kg}^{-1} \mathrm{~W}^{0.75}\right)$, Japanese millet $\left(67.3 \mathrm{~g} \mathrm{~kg}^{-1} \mathrm{~W}^{0.75}\right)$ and sorghum silages $\left(69.8 \mathrm{~g} \mathrm{~kg}^{-1} \mathrm{~W}^{0.75}\right)$. The higher DM voluntary intake of rice crop silage was, thus, poorly consistent with the digestibilities of DM and crude fiber. This was not in agreement with a positive correlation between intake of roughages and their digestibility by ruminants ${ }^{1,2)}$. According to $\mathrm{BALCH}$ and CAMPLING ${ }^{2}$, the food intake of ruminants is restricted primarily by rumen capacity and hence by the rate of digestion and passage of roughages.

Eating time ( $\mathrm{min} . \mathrm{kg}^{-1} \mathrm{DM}$ intake) was the shortest for rice crop silage among the crop forages tested, because of less searching of cattle fed on rice crop silage. It was indicative of higher palatability of this material which was probably associated with less differences in palatability between leaves, stems, and grains. As compared within variety, a higher DM content has been found partially to contribute to a shorter eating time and higher voluntary intake. However, the extent to which a higher DM content of rice plant compared to the other crop forages can contribute to shorter eating time and higher DM voluntary intake of this material was not known.

Chewing speed per bolus of rice crop silage was slower than those of other silages, indicating greater physical resistance of rice straw which was resulted in lower digestibility of crude fiber. Rice crop silage was also found less in rumination time ( $\mathrm{min} . \mathrm{kg}^{-1} \mathrm{DM}$ intake) than those of Italian ryegrass and sorghum silages and similar to that value of Japanese millet.

In this study some amount of intact rice grains was detected in the cattle feces, in agreement with the previous results obtained for corn (Zea mays L.) ${ }^{7)}$ and rice (Oryza sativa L. $)^{8,9)}$. NAKUI et al. ${ }^{8)}$ reported on the nutritive values of whole crop rice silages that a 18 $\%$ of grains was intact in the cattle feces. Thus, a higher voluntary intake of whole rice crop silage compared to the other forage crop silages may be due to some amount of intact grains which involve a higher passage rate of this whole plant through the alimentary tract of cattle $e^{2,5,1212)}$, as shown in both negative relationships between chewing speed and rumination time and between digestibility and voluntary intake.

Consequently, the voluntary intake of TDN of rice whole crop silage was similar to those of Italian ryegrass and sorghum silages, but higher than a millet silage.

\section{Acknowlegement}

The authors sincerely wish to thank Mr. Y. Ito, Mr. N. Sakamoto and Mr. Y. Yotani in the Mie Animal Husbandary Experimental Station, for providing the valuable opportunity to work with their cattle and facilities.

\section{References}

1) Baile, C.A. and J.M. Forbes, Control of feed intake and regulation encrgy balance in ruminants. Physiological Reviews., 54 : 160-214. 1974.

2) Balch, C.C. and R.C. Campling, Regulation of voluntary food intake in ruminants. Nutrition Abstract and Reviews., 32 : 669686. 1962.

3) Goto, M., A. Nishijima and O. Morita, Comparisons of nutritive values between sorghum silage and foggage. Jpn. J. Zootech. Sci, 59 : 541-547. 1988.

4) Haryu, T., in "Esamai" no GijyutsutekiTenbou (Tsukuba Nouringijyutsu o kangaerukai eds.) 97-104. Nourintokeikyoukai. Tokyo. 1982.

5) Hashizume, T., H. Fujita, S. Matsuoka, H. Kato and G. Sato, The effect of different forms of roughages on the digestibility, rumen fermentation and mean retention time in the alimentary tract. Res Bull. Obihiro Univ., 9 : 491-508. 1975.

6) Horir, S., in Dobutsu Eiyou Sikenho (Edr. Morimoto, H.) Youkendo. Tokyo. 280-297. 1971.

7) Nakui, T., R. ABe, K. Iwasaki and M. HaYAKaWA, Toumorokosi-silage chumo sijitsuga gyuhunchuni haisetsusareru 
Feeding Value of Rice Whole Crop Silage as Compared to Summer forage crops

wariai. J. Japan. Grassl. Sci,, $23: 84-85$. 1977.

8) NakuI, T., N. Yahara, S. TakaI, Inewhole crop no setsudannchou ga silage no hatsukouhinsitsu to mishouka sijitsu haisetsu ni oyobosu eikyou. Jpn. J. Zootech. Sci., 77th Annu. Meeting Abstr. 10. 1985.

9) Norinsuisansho Sougoukenkyu (S. 57-S. 61), Tohoku Nogyoushikenjyo Kenkyuseika (S. 58) 233-234. 1983.

10) Ohyama, Y., in Doubutsu Eiyou Sikenho (Edr. Morimoto, H.) Youkendo. Tokyo.
412-427. 1971.

11) ReEs, M.C. and D.J. Minson, Fertilizer calcium as a factor affecting the voluntary intake, digestibility and retention time of pangola grass (Digitaria decumbens) by sheep. Br. J. Nutri., 36: 179-187. 1976.

12) Thornton, R.F. and D.J. Minson, The relationship between voluntary intake and mean apparent retention time in the rumen. Aust. J. Agric. Res., 23 : 871-877. 1972. 